\title{
Promotion of On-line Reading Competition of Tuku Vocational High School's (TKVS) Library in Taiwan
}

\author{
Hao-Yen Wu \\ Director of Academic Affairs Office \\ National Tuku Vocational High School \\ Taiwan
}

\begin{abstract}
An on-line reading competition is a great way to enhance the knowledge management and a method to attract student's interest in utilizing the books as their primary source to master the multi-facets of literacy and to prepare for their examinations. The purpose of this paper will show what measures will be taken to promote on-line reading competition.
\end{abstract}

\section{Introduction}

Rather than using books from the library, a typical Asian student preferred studying from their textbooks to help them pass the college entrance examination. This tendency was the same in a small suburban town in Taiwan like Tuku, an area that has 46 square kilometer and a population of 32,000 people of which $70 \%$ is farmers. Due to many revisions to the textbooks, the exam content has changed a lot from the past to the present. In order to master the examination, multiple facets of literacy should be focused. In theory, the library should be gaining more popularity than before. Unknown to others, an on-line reading competition is a great way to enhance the knowledge management and a method to attract student's interest in utilizing the books in the library as their primary source to master the multi-facets of literacy and to prepare for their examinations. For a small town, like Tuku, the purpose of this paper will show what measures will be taken to promote on-line reading competition.

The promotions that will be utilized by the school are as followed:

- Create a Library tour 
As a result of providing a library tour, this will allow its partakers to be familiarizing with various web aspects of the on-line reading competition as well as how to utilize its vast resources. Because of their fear of unfamiliarity, this introduction will allow an easier transition for people, who are unfamiliar with the on-line competition.

\section{- Introduce a library website for middle-school students---An on-line reading competition website}

By interfacing various nation-wide librarian websites to our school homepage, this will provide its users a common interface to where they can go search or complete whatever they need using our homepage's vast resources. Through the convenience of the web, on-line reading is just a click away for its users.

\section{- Provide incentives for the top 3 students who are most active in utilizing on-line resources from the library}

By giving incentives to the top 3 students who are most active in utilizing on-line resources from the library, this will encourage everyone to use its benefits. At the same time, this is an excellent opportunity for everybody to enhance or to reinforce their knowledge.

\section{- Continue to show support for improving Students and Teachers Reading Club}

Student and Teacher Reading club is an excellent organization that will promote various benefits of the library as well as a tool to improve its participants' literacy skills. Through its various types of activity, its members will be familiarizing themselves with the library as well as giving an opportunity to discuss and to listen for ways to expand their literacy ability. In the future, they will be prepared for any reading/writing competition by using the internet.

\section{- Publish and advertise "TKVS YOUTH"}

"TKVS YOUTH" is a published booklet that is printed twice a year to allow its students to write and express their thoughts. Additionally, every semester it prints the "Top3 Students reports" on TKVS YOUTH for excelling in their on-line reading competition in Yunlin County as well as awarding them with a scholarship.

\section{- Purchase books/magazine that is popular with the students}

There is not a better method to attract interest from its students by providing books or magazines that's "in". By giving them a reason to visit the on-line librarian web, this gives them an opportunity to read and to improve their literacy skills as well as a way to acquaint themselves with its various reading benefits. 


\section{Conclusion}

Through these promotions, the students will get acquainted with the on-line reading competition and its vast resources. Due to these benefits, they will recognize this as a vital source of information. From these interactions, it will enhance the various aspects of the library and its on-line reading competition website. At the same time, it will expand its role in the knowledge management. For a remote area like Tuku, the purpose of this paper will show the measures will be taken to promote more on-line reading and writing.

\section{Author Note:}

Hao-Yen Wu had been the director of library in TKVS from August 2003 to February 2007. After serviced in Hardee's restaurant as an assistant manager and in an international trade company as a sales manager for 2 years, he went to USA to gain a bachelor degree in business and a master degree in accounting. Lecturing in Transworld Institute of Technology for 7 years, he teaches marketing and accounting in Tuku vocational high school.

\section{Tuku:}

Tuku has an area that has 46 square kilometer and a population of 32,000 people of which $70 \%$ is farmers. It will take 3.5 hours drive from Taipei to Tuku.

TKVS:

The Tuku division of Chia-Yi Business Vocational High School was established in August 1955. In August 1969 the school was renamed The Taiwan Provincial Tuku Vocational High School of Commerce and Industry. Finally, the school was renamed National Tuku Vocational High School of Commerce and Industry. It has 88 teachers and 1137 students including vocational and comprehensive high school. Ms. Chiung-yu Tsai is the sixth principal right now. 